\title{
İlhan Berk'in Şiirlerinde İstanbul Teması
}

\section{Nurullah ULUTAȘ}

\section{Özet}

İstanbul, hemen her dönemde Türk şiirinin vazgeçilmez temalarından biri olmuştur. Birçok şairin övgüyle bahsettiği bu şehir, İlhan Berk'in şiirlerine farklı görünümleriyle yansır. İlhan Berk, İstanbul'u sevmekle kalmaz; onu bütün semtleri ve sokaklarıyla şiire sokar. Tasvir ettiği bu yerleri; ressamlığının etkisiyle okuyucunun gözünde canlandırmayı başaran şair, tarihî semtleri en ince ayrıntısına kadar betimler. Onun şiirinde İstanbul, işçileriyle, yoksullarıyla, açlarıyla, hastalarıyla, balıkçılarıyla ve kadınlarıyla vardır. Bu yaklaşım onun toplumcu kişiliğin yansıması olarak şiire girer. Yaşadığı şehre sâdık olan şair, onu bütün detayıyla şiirine eksen kılar. Bu çalışmada, İlhan Berk'in bütün şiirleri incelenerek onun İstanbul'a bakışı değerlendirildi. Şiirlerimiz için önemli bir şehir olan İstanbul'a, farklı bir şairin penceresinden bakmak amaçlandı. Bu çalışma yapılırken analiz ve yorum metodları kullanıldı. Çalışmanın sonunda İstanbul şehrinin İlhan Berk'in şiirinde diğer şairlerin şiirlerinden farklı olarak işlendiği görüldü.

Anahtar Kelimeler: İlhan Berk, Türk Şiiri, İstanbul, İkinci Yeni, Eleştiri

\section{İstanbul Theme In İlhan Berk's Poetry}

\begin{abstract}
İstanbul has been one of the indispensable themes of Turkish poetry in almost every period. The city about which most of the poets mention by praising is reflected in different views in İlhan Berk's poetry. Not only he admires the city but also he makes his poetry with the whole neighborhoods and the streets of this magnificent city. The poet who managed to visualize these places with the impact of being a painter describes the historical neighborhoods in a detailed way. In his poetry, İstanbul appears its workers, the poor, hungers, the patients, fishermen and women. This approach enters in his poetry as a reflection of his social personality.

The poet who is faith to the city where he lives has taken it with all its details to the axis of his poetry. In this study, The view of Illhan Berk to Istanbul has been reviewed by analysing all of his poems. It is aimed to have a perspective of another poet to Istanbul that is an important place for the poems. Analysing and comment method is used while doing this study.At the end of the study, It is seen that Istanbul city is dealt with different ways in the poems of Ilhan Berk from the poems of others.
\end{abstract}

${ }^{a}$ Yrd.Doç.Dr., Alparslan Üniversitesi,Eğitim Fakültesi, nurullahulutas16@hotmail.com, Muş. 
Key Words: İlhan Berk, Turkish Poem,İstanbul, Second New Style of Turkish Poem , Criticism

\section{Giriş}

İstanbul, gerek coğrafî konumu, gerekse tarihî ve kültürel kimliği bakımından sanatçıların ilham kaynağı olmaya devam edegelmiştir. Fethedildikten sonra yaklaşık beş yüz yıl Osmanlı Devleti'nin başkenti olan; kültür ve sanat hayatının dokusunu üzerinde taşıyan İstanbul'un genelde Türk edebiyatı; özelde Türk şiiri üzerindeki tesiri yadsınamaz. Hem Halk şiiri, hem Divan şiiri hem de Modern şiirimizi, İstanbul'dan ayrı düşünmek imkânsızdır. Dede Korkut kitabında bezirgânların alışveriş yaptıkları bir şehir olan İstanbul, Tuhfetü'l-Uşşak adlı mesnevide halk hikâyelerinin gerçekleştiği mekân olarak yer alır. Halk şiirinde Âşıı Ömer, Ahmed; Divan şiirinde Fatih, Ahmed Paşa, Aynî, Celîlî, Tâcî-zâde Cafer Çelebi, Zati, Baki, Nihânî, Zihnî, Sirozlu Sâdi, Yahya Efendi, Koca Nişanc1, Şeyhülislâm Yahya, Nâbi, Vecdi, Fasihi, Nef'i, Şeyh Gâlib, Nedim, Nahifî, Esrar Dede ve Enderunlu Vâsıf gibi şâirler İstanbul'u şiirlerinin önemli temalarından biri olarak işlemişlerdir. ${ }^{1}$

İstanbul, Nedim'in: "Bu şehr-i Stanbul ki bî misl ü behâdır / Bir sengine yek pâre Acem mülkü fedâdır" beytinde doruğa çıkan bir övgüyü hak eder. Sarayın orada bulunması İstanbul'a merkez olma pâyesi verir. Abdülhâk Hâmid Tarhan, Sami Paşazâde Sezâi, Mehmed Tâhir, Recâizâde Mahmûd Ekrem, Mehmed Celâl gibi şâirler yazdıkları eserlerde İstanbul'u övgüye mazhâr bir şehir olarak işlerler. Ziya Paşa ve Tevfik Fikret'in İstanbul'a olumsuz yaklaşımları daha çok siyâsî otoriteye muhalif olmalarıyla ilgili bir durumdur. ${ }^{2}$ Akif, İstanbul'u realist gözlemleriyle sokaklarına kadar tasvir eden bir şair olarak özgün bir tavır sergiler. Cumhuriyet dönemi şâirleri İstanbul'u daha çok coğrafi güzellikleri, sosyal yaşantısı ve tarihsel dokusuyla şiirlerinde işlerler.

İkinci Yeni şairlerinden İlhan Berk de İstanbul'u hemen tüm boyutlarıyla şiirlerine aktaran bir şairdir. İstanbul; şairin İstanbul Kitabı (1947), Günaydın Yeryüzü (1952), Galile Denizi (1958), Çivi Yazısı (1960), Şenlikname (1972), Atlas (1976), Delta ve Çocuk (1984), Galata (1985) ve Pera (1990) gibi

\footnotetext{
${ }^{1}$ Kaplan, 1999, $\quad$ s. $42-45$

2 Ulutaş, Nurullah, "Ziya Paşa ve Tevfik Fikret'in İstanbul'a Bakışı”, Seyir, S. 4, Bahar 1998, s. 31-32
} 
kitaplarına farklı görünümlerle yansır. $\mathrm{Bu}$ yansımaları şu başlıklar altında incelemek mümkündür:

\section{A. İstanbul Sevgisi}

İstanbul, İlhan Berk'in şiirlerine zaman zaman olumsuz intibâlarla yansımış olsa da şiirlerinin genelinde yoğun bir İstanbul sevgisi olduğunu görmek mümkündür. O, 1 Nisan 1962 tarihinde, Varlık Dergisi'nde, Muazzez Menemencioğlu'yla yaptığı bir söyleşide, İstanbul üzerine yazdığı şiirleri daha çok o şehirde yaşamasına bağlar. " "Ağacın Her Sabahki Duyduğu" şiirinde olduğu gibi, onun şiirindeki İstanbul, sadece insanın gönlüne hükmetmez; bir serçenin yüreği bile İstanbul sevgisiyle doludur:

"Bir bize mahsus değil

Dünyayı vazgeçilmez bulmak

Bir serçe tanırdım ki ben

Yüreğini yarıp baksaydınız

Bir gökyüzü bulacaktını eminim

Eminim İstanbul'dan." (Toplu Şiirler, s. 90)

Serçenin yüreğinde İstanbul'a ait bir gökyüzü bulma anlayışı II. Yeni akımına bağlı şairin usu allak bullak etmesiyle ilgili bir yaklaşımdır. ${ }^{4}$ Şiirde geçen "gökyüzü" imgesi, umudu imler.İlhan Berk'in sözcüklerle oynama, onlara yeni anlamlar yükleme yeteneği bu şiirde açıkça görülür.

\section{B. İstanbul'un Semtleri}

Birçok medeniyete beşiklik etmiş İstanbul, o medeniyetlerin izlerini semtlerinde gizler. Karaköy, Beyoğlu, Ortaköy, Haliç, Üsküdar, Kadıköy, Pera, Süleymaniye, Çırağan... İlhan Berk'in şiirlerinde ayrı hikayeleri olan

\footnotetext{
${ }^{3}$ İlhan Berk'te yaşadığı kenti anlatma zorunluluğu vardır: "Ben dünyanın neresinde yaşıyorsam, oraya, oranın insanına, coğrafyasına, tarihine, doğasına bakmadan; sonra da orayı yazmadan yapamam. Her şey benim için yazılmak için var. Kimi zaman yalnız doğadır, tarihtir gördüğüm, kimi zaman salt insan yaşamı: Dünyaya bu bakışımda da kendimi zorlamam, bırakırım. İlgi alanım beni nereye sürerse, o yöne giderim. Yaşamıma ben değil, yaşam bana egemendir. Yani ben şiiri değil, şiir beni istediği yere götürür." (Ünlü ve Özcan, 1990, s. 327)

4 “.(...) Şiirin öğelerini, ilkelerini saptamak, kendi ilkelerinin dışındaki bütün öbür araçları atmak, şiiri şiir olarak ama bir şiir olarak düşünmek yani. İkinci Yeni şiir, ilk bunu düşünüyor işte. Ben bundan daha büyük bir sorunluk bilmiyorum...

Şimdiye değin anlamın bir yönü biliniyordu bizde; usa bağlı yönü. Oysa şiirin en yüce öğesi, usu allak bullak etmesi, onu yıkmasıdır...” (Ünlü ve Özcan, 1990, s. 522)
} 
semtlerdir. İlhan Berk'in çoğu şiirinde kişileştirilen bu semtler tüm canlılı̆̆ıyla okuyucunun gözünde canlanır. O, İstanbul'u bazen büyük bir kitaba, bazen vazgeçilmez bir arkadaşa, bazen de insanlığın haline benzetmekten kendini alamaz. ${ }^{5}$ Şairin semtleri tasvirdeki başarısında, ressam kişiliği yanında ${ }^{6}$, Paul Klee'den etkilenerek resme duyduğu ilgiyi de yadsımamak gerekir. ${ }^{7}$

"İstanbul" başlıklı şiirinde canlı bir tasvir çizer:

"İşte kurşun kubbeler şehri İstanbul'dasın

Havada kaçan bulutların hışırtısı

Karaköy çarşısından geçen tramvayların camlarına yağmur yağıyor

Yenicami Süleymaniye arkalarını kirli bir göğe vermişler

Hiç kımıldamıyorlar Ayasofya elleriyle yüzünü kapamış bütün iştahıyla ağllyor." (Toplu Şiirler, s. 41)

"Bir kuleyim ben İstanbul'da. Bir sabah İstanbul'u yaktım. İlk oturduğum sokağı yaktım. Hâla anımda bir çocuk, yarı soyunuk bir kadın, bir akşamüstü anımda. Kuşları, ă̆açları yaktım. Kuşları, ağaçları yanmaz diye biliriz biz değil mi? Yaktım. Gördüm dünyalara değişilmezdi ă̆zı. Ă̆zı nehirleri, dükkanları, güneşleri, trenleri, yolları, çarşıları hatırlattı durdu bana. Kollart sicak nehirleri tutuşturdu bütün gece, bütün gece dünyada değilmişiz gibiydik.” (Toplu Şiirler, s. 227)

\footnotetext{
5 “İstanbul'u hep büyük bir kitap vazgeçilmez bir arkadaş diye tanımladım. Dahası, İstanbul gibi bir kenti olan bir yazar başka bir şey istememeli diye de yazdım. Giderek, onu insanlığın haline benzettiğimi de ekledim: Geçmişiyle, şimdisiyle yıkık bir insanlık; ama geleceğiyle inançlı, güvenli... İstanbul böyle bir şey benim için. Ondan kopamıyorsam, neden bu: bir kentten çok, bir insanlık halidir benim için İstanbul. Türkiye'nin tarihini de, coğrafyasını da yazan odur. Kan, onda bulur kanlığını, o biçimler derim." (Ünlü ve Özcan, 1990, s. 327)

6 "Bir de ressam İlhan Berk vardır. Nü’ler çizer kâğıtlara, kitap sayfalarına, her yere. Nü'ler; deforme olmuş kadınlar; var olan kadınlar değil, çizgiden ibaret kadınlar; ama mutlu çizgilerdir bunlar. Çünkü İlhan Berk için resim yapmak mutluluk, yazmaksa cehennemdir. Resim aracılığıla dünyayı olduğu gibi görmez ve en önemlisi kendisine yeryüzünü cehenneme çeviren yazmak eyleminden kurtulur. Kadınlar bu nedenle kalın birer çizgidirler şiirinde. "Mutlu insan yazmaz, yazmak mutsuzluktur' diyen İlhan Berk'in şiirinde kadının ayrıcalıklı bir yeri yoktur; "Her nesne nasılsa kadın da öyledir" hatta." Faize Özdemirciler, "Kadın Bir Nü, Aşk Bir Resim, Şiir Büyük Eziyet..."http//www.afrikapazarı.net. (28 Eylül 2008/Pazar)

${ }^{7}$ Karaca, Alaattin, "İlhan Berk'in Şiir - Resim Etkileşimi”, Türk Edebiyatı, S. 423, Ocak 2009 (http://www.yeniturkedebiyati.com/makale/ cumhuriyet_devri_turk_ edebiyati/530-ilhan-berkte-siir-resim-etkilesimi-doc.-dr..html)
} 
Kendisini Galata Kulesi'yle özdeşleştiren şair hatıralarının gizlendiği şehri yakarak geçmişinden kurtulmanın yolunu arıyor. ${ }^{8}$ İlhan Berk'in şiirlerindeki İstanbul tasviri Akif veya Fikret'in şiirlerindeki tasvirlerden farklı olarak empresyonist bir bakış açısıyla nesnelerin şairin ruh haline bağlı olarak kimlik değiştirmeleriyle ortaya çıkar. ${ }^{9}$ Diğer şiirlerinde olduğu gibi nesnelere ve kadına erotik bir anlam yükleme bu şiirinde de ortaya çıkar. ${ }^{10}$

İstanbul'un semtleri ve İstanbul'un sokaklarıyla özdeşleşmiş isimlerle kendini bir tutan şair, Beyoğlu semtini günlük telaşı içinde en yalın görüntüsüyle şiire aktarmayı başarır. Tasvirlerindeki başarısında, yukarıda da değindiğimiz gibi, resim yeteneğinin etkisi yadsınamaz. "Bileyci Niko Margarit" şiirinde:

"Ben kimim mi diyorsunuz siz

Tuhaf, bileyci Niko Margarit

Bıçak bilemektir benim işim

Her canım bulutsuz cumartesi akşamı

Yağcı Boris Nihas, karidesçi İsmail

Bir fena çocuk bir aşağı bir yukarı Beyoğlu’nda

8 "Psikologlar bazı ruh hastalarının yangın çıkarmaktan cinsi bir haz duyduklarını tesbit etmişlerdir. 'Galile Denizi'nde "Galata Kulesi” adlı şiirinde, İlhan Berk'in de yangınla cinsi arzuyu birleştirdiğini görüyoruz. İnsanlarla arasında hakiki bir "communication" kuramayan, koca şehirde kendi yalnızlığına gömülü olarak yaşayan şair, onları bir karaltı gibi görüyor." (Kaplan, 1996, s. 209)

9 "Şiirde İstanbul (şehir-tabiat ve insanlar) Tevfik Fikret'in "Sis"i yahut Mehmet Akif' in bazı eserlerinde olduğu gibi teferruatlı ve insicamlı bir tablo teşkil edecek şekilde tasvir olunmamış, şairin ruh hallerine bağlı sembolik mana taşıyan bazı unsurlarla verilmiştir. Bütün kitapta olduğu gibi burada da her şey şaşırtıcı bir şekilde birbirine karıştırılmıştır. Fakat dikkatle bakılınca, şiirin modern resme has estetik bir nizama sahip olduğu, bazı unsurların birbirine cevap verdiği görülür. İlerde belirtileceği üzere, İlhan Berk bu eserini yazarken modern resim tekniğinden de faydalanmıştır." Kaplan, 1996, s. 197 - 198

10 “İlhan Berk'e göre İstanbul'un bir şehir olarak dünkü ve bugünkü hali korkunçtur. Buna karşılık onu çeviren tabiat, deniz, gökyüzü ve güneş çok güzeldir. "Balad" şiirinde, bu tezat kuvvetle belirtilmiștir. "Pis İstanbullar"dan iğrenen eski surlar, kötü evler ve dar sokaklardan içi sıkılan şair, "büyük ulu sular”da yıkanır. Gökyüzüne bakarken genişlediğini hisseder, güneşin ışıklarıyla adeta sarhoş olur.” (Kaplan, 1996, s. 203)

11 "Ben, resme çok meraklı bir adamım. İllüstrasyonları, gravürleri toplar, inceler, üstlerindeki yazıların anlamlarını çözmeye çalışırım. Eski bir İstanbul gravürü, birdenbire ilgilendirir. Oturur, incelerim. Bu, daha sonra beni yazmaya götürecektir." Berk, 2005, s. 32 
Bir cam klracak olsa bulutlar

Ben görürüm herkeslerden önce

Bir şiirde bir kadin soyunsa

Önüne gider dururum

Bıçak bilemektir benim işim

Her Allah'ın günü gökyüzüne karşı." (Toplu Şiirler, s.223)

"Gökyüzü” imgesi gerek Türk şiirinde gerekse dünya şiirinde yoğun olarak kullanılan bir imgedir. İlhan Berk'in "İlk Gökyüzü Çekip Gitti” şiirinde İstanbul fotoğrafı çizen şair, erotizme varan tasvirler çizmekten geri durmaz:

"Illk gökyüzü çekip gitti

Gökyüzünün önünde Hiristaki Pasajl, Amerikan Haberler

Bürosu,Saint-Antoine'daki Lambodis 'in meyhanesi gökyüzünün önünde

Sonra hiç düşünmediğimiz saraylar, Çırağan, Yıldız, Teodora'nın kahve fincanları, güneşler, sokaklar

(...)

Hani öldürecek kadar güzel, haşhaş çiçeklerine, kızlara, çocuklara benzeyen

Üzerlerini açan

Hani çarşaf gibi

Hani ak

Hani katil olan

İste o gökyüzü

Galata Kulesi'nin üstünden kalktı

Denizle gitti." (Toplu Şiirler, s.229)

1972 yılında yayınladığı Şenliknâme adlı kitabının "İstanbul" başlıklı şiirinde bu şehri, kültürü, mimarisi, anıtlarıyla Bizans kalıntılarından arta kalmış bir şehir olarak tasvir eder:

"Küçük, yatık bir dikdörtgen. Ve bir tümce: Istanbul,1574; BraunHogenberger.Gravür.

Bir altyazı. Gotik bir resim üstü yazısını ortaliyor: BYZANTYUM LUNC CONSTANTINOPOLIS (böyle okuyorum). Belli Hogenberg'in elinden çıkmış. Giderek resmi dokumaya başlayacaktır: çizgiler, üçgenler, dörtgenler inip. Dikeyler çıkıp Alımlı Özerkli. Hogenberg'in alfabesini kurmak için. Dönüşüp bir büyük sözlüğe ISTANBUL adlı Tahtadan. Değil mi ki bir gravürdür. Kazllacaktır, çelik bir kalemle. Baka baka bir taşbasmasina." (Toplu Şiirler, s.343) 
İlhan Berk'in şiirlerinin çoğunda İstanbul, Müslüman kimliğinden ziyade Haçlı ve Bizans kimliğiyle ön plana çıkar: "Diğer şiirlerinde de parça parça İstanbul şehrine ait unsurlar vardır. Bunların çoğu Beyoğlu, Yüksek Kaldırım semtlerini hatırlatırlar. Şairin hususi bir duygu ile sevmesine rağmen bunların hemen hepsi de çirkin ve iğrenç bir tesir bırakıyor. Bazı şiirlerinde adeta Bizans devletinin yıkılmasına üzüldüğü hissedilen yazarın, Türk tarihi karşısında almış olduğu tavır, diğer Marksist şairlerde olduğu gibi menfidir."12

İlhan Berk, "Filibe" adlı şiirinde, İstanbul'u bir yer altı kenti ve Haçlılara ait bir yer olarak olarak tanıtır:

"Bir ok işareti ve bir sözcük: ISTANBUL:444 km.

Istanbul bir yer altı kenti ve Haçlılar mı? " (Toplu Şiirler, s.493)

1976 yılında yayınladığı Atlas adlı şiir kitabındaki "İstanbul - III" bölümünde yer alan "Üsküdar" adlı şiirinde de Haçlılara ait bir fotoğraf görürüz:

"Kokular sana "Üsküdar'dasin” diyor, Üsküdar'da, Khripolis'te Kokulara 'Üsküdar'dayım' diyorum, Üsküdar'da çıkmaz bir sokakta

Ve ayl oynatzyor bir adam ve sarı. Sart

Bir çocukla dolaştı̆̆ından Üsküdar' ’” (Toplu Şiirler, s.446)

İlhan Berk'in şiir anlayışı her ne kadar II. Yeni akımının etkisiyle soyut ve halktan uzak bir nitelik arz etse de halk ve divan divan şiirinden beslenen bir şiirdir. ${ }^{13}$ Onun şiirinde insanlar, nesneler, eşyalar, bitkiler v.s. özel bir yere sahiptir. Eşya ve insana olan ilgisi onu bir sözlük hazırlamaya kadar itmiştir. ${ }^{14}$

1976 yılında yayınladığı Atlas adlı şiir kitabındaki "Haliç" başlıklı şiirinde Haliç’i gülümseyen çocuk dişlerine benzeten şair, İstanbul semtlerini kişileştirerek canlı k1lma yoluna başvurur:

“Ve haliç çocuk dişleri gibi Gülünce.” (Toplu Şiirler, s.423)

\footnotetext{
${ }^{12}$ Kaplan, 1996, s. 201

${ }^{13}$ Akkanat, 2002, s. 148

14 “1974-1975 yıllarımı "Berk Sözlüğü” aldı. Zaman zaman hâlâ da sürüyor bu. Benim sevdiğim, ilgi duyduğum insanlar, nesneler, hayvanlar, bitkiler sözlüğü bu. Benim yaşamıma vurmuş, benim yaşamıma karışmış bir dünyanın dökümü. İki yıldır bu dökümün çetelesini tutuyorum.” (Nesin Vakfı Yıllığı - 1976, 1976, s. 436)
} 
İlhan Berk; 1941 yılında yazdığı "At Kestanesi" şiirinde, dostu Bedri Rahmi Eyüboğlu ile birlikte oturduğu Beyazıt Kahvesi’nde İstanbul'u bir ağacın gölgesine yerleştirerek resmeder:

"Değil mi ki Beyazıt alanındayız ve bindokuzyüzkırkbirlerde, cebinde İstanbul" (T.Ş, s.527)

"Ece Ayhan" adlı şiirinde II. Yeni şiirinin önemli şairlerinden ve dostlarından Ece Ayhan'1 Üsküdar'la özdeşleşmiş tarzda anlatan İlhan Berk, aynı şiirde hem İstanbul'un hem de edebiyatımızın özetini vermeyi ihmal etmez:

“Adasından hiç inmez mi? İner elbet. Üsküdar'sız yapamaz. Daha haramilerin ayak basmadiğı Üsküdar'slz. Hem değil midir ki, oradan bir adımda Sirkeci'de, yeni Cumhuriyetinde olabiliyordur, inecektir elbet.

(...)

Valde Atik'de Eski Şair Çıkmazı'nda oturur

Saçları bir sözle örülür bir sözle çözülür. (Toplu Şiirler, s.694)

Şair, Pera'nın sokaklarında akşam yürüyüşüne çıkarken, hatıralar bir çamur gibi tabanına yapışır. Şiirde geçen çamur imgesi, şiirde hem sevgiliyle yaşanan olumsuz hatıraları hem de İstanbul'un olumsuz yüzünü simgeler:

"Pera'nın eski bir sokağını tepiyorum ben böyle her akşam

Her akşam tabanımda senin çamurun." (T.Ş, s. 712)

"İstanbul Önünde İki Balık" şiirinde Üsküdar semti, şairi sarhoş eden bir güzelle birlikte girer şiire:

"Daha bin yıl yaşasin şu Üsküdar önü

Önümden geçen kizın neydi o saçları

Biraksa yeminle sarhoş ederdi havayl

Ömrüm oldukça ben bu kıyıdan ayrılmam" (Toplu Şiirler, s.108)

Delta ve Çocuk adlı kitabındaki "Ortaköy" şiirinde tasvir ettiği Ortaköy semti de ortaçağdan kalma bir görüntüyle şairin hatıralarını hüzünlü bir edayla dile getirir:

" Sanki iki Ortaçağllyız akşamın elinde

Ve çok eski bir gravüre çıkıyoruz

Ve Ortaköy'deyiz

Ortaköy'de bir sokağı tepiyoruz bir yapră̆ı ya da

Bir yaprak da tepilen bir şeydir biliyorsun” (Toplu Şiirler, s.885) 
Ulutaş , N. / Sosyal Bilimler Araştırmaları Dergisi. 2, (2009): 129-149

"Minyatüre Çıkmayan Galata Sokakları Baladı" adlı şiirde de İstanbul'un semtleri sokaklarıyla şiire yansır. $\mathrm{Bu}$ şiirlerde konuşan sokaklar kimliklerini ele verir:

"Bir bulut üstüme üstüme geliyor diyor Bergamut Sokak (atlı kllığında bir bulut)

Kadem Sokak yine yükünü tuttu gözü hiçbir şey görmüyor diyor Leblebici Şaban Sokak

Alageyik Sokak'tan sesler geliyor diyor Mangır Sokak bir adamın kan akıyor yüzünden.

Bütün gün bir güzel yüz geçmedi diyor Şair Eşref Sokak koca gün böyle geçti diyor. (T.Ş, s.1730)

\section{C. İşçiler ve Yoksullar}

İlhan Berk, her ne kadar II. Yeni'nin soyut, halktan uzak ve imgeci anlayışını temsil eden aydın tipi / şair olarak anılsa da özellikle ilk dönem şiirlerinde toplumsal temaları yoğun olarak kullanır. ${ }^{15}$ Onun şiirlerinin çoğunda İstanbul, insanıyla birlikte vardır. Şair, insanları doğal halleriyle ele alır. Yahya Kemal'in şiirlerinde sanat, tarih, kültür ve medeniyeti simgeleyen İstanbul'daki âsude insanların yerini, İlhan Berk'in şiirlerinde yoksul insanlar ve işçiler almıştır. Şehir arabesk bir kimliğe bürünmüştür. ${ }^{16}$ İstanbul'un gündelik hayatı ve trafik karmaşası içinde şiire yansıyanlar, işten dönen çileli ve yoksul insanlardır. Şair, ayrı hikâyelere sahip bu insanları bir karede toplamayı başarır.

"Insanlar sokak sokak çarşı çarşı ev ev

Insanlar sirt sirta omuz omuza verip durmuşlar

Boyunları bükük

Yorgun asabi kindar

Yığın yığın olmuşlar hepsi köprünün açılmasını bekliyor

Fatihliyle Beşiktaşlı sarmaş dolaş olacak”" (Toplu Şiirler, s. 41)

15 “1939-47 yıllarında yazılan bu şiirlerde boyunları bükük, yorgun, sinirli, kinci, İstanbul insanlarını; işçi, kömür işçisi, tezgahtar kızlar, yol ameleleri, vapur işçileri, hamallar, duvarcılar, ırgatlar, kayıkçılar ile bu insanların sabah işlerine giderkenki durumlarını, iş sırasındaki gözlemlerini anlatır ... Artık ilhan Berk dünyaya, insanlara bakış açısını değiştirmiş, metafiziği bir kenara itmiştir. Maddeci bir dünya görüşü egemendir.” (Ünlü ve Özcan, 1990, s. 326)

16 Karaca, Alâattin; "Yahya Kemal'in İstanbul'undan İlhan Berk'in İstanbul'una", Hürriyet Gösteri, S. 296, Aralık, Ocak, Şubat 2008-2009 
O, toplumun her kesiminden yoksul insanları, işçileri Nazım Hikmet'in etkisiyle, toplumcu gerçekçi bir bakış açısıyla irdelemeyi ihmal etmez. ${ }^{17}$ İşçiler, onun şiirinde tüm çıplaklığıyla tasvir edilir. Şair, hepsini çok iyi tanır, çalıştıkları, kaldıkları yerlere giderek, hepsinin ayrı trajedilerle yüklü hikâyelerini dinler ve bunları okuyucuya aktarır. İlhan Berk'in özellikle gençlik yıllarında yazdığı şiirlerde devrimci bir bakış açısıyla toplumu ve İstanbul'u işlediği görülebilir. ${ }^{18}$

"Sarı uzun yüzlü cesur işçiler

Dört köşe halinde veya dağınık bir şekilde durmuşlar

Hiç konuşmuyorlar

(...)

Bu en önde gidenler

Tophane'de Dikimevi'nde çalışır

Sekiz kızdır ancak üçü evlenmiştir

Bu saçları darmadağın asık suratlı delikanlılar

Kömür işçisidir

Bu üç klz Beyoğlu'nda büyük bir mağazada tezgâhtar

Bunlar yol amelesidir

Bunlar vapur işçisi

Öbürleri duvarcı hamal ırgat kayıkçı

Hepsi bu gök altında sarmaş dolaş olmuş yürüyorlar."

(Toplu Şiirler, s. 41)

İlhan Berk, şiirini her ne kadar alegorik unsurlarla oluşturup İkinci Yeni'nin toplum üstü anlayışını benimsese de onun şiirlerinde Marksizm'e dayalı toplumsal bir duyarlılık öne çıkar. O, birçok şiirinde kullandığı imgelere sosyal bir anlam kazandırmayı başaran bir sanatçıdır. ${ }^{19}$

17 "Sanat hayatının birinci döneminde Garip hareketinden ciddi anlamda etkilendiğini görüyoruz. İkinci döneminde İkinci Yeni'nin 'folkloru şiire düşman' belleyen söylemine rağmen, duyuş konseptini daha da genişleterek Nazım Hikmet kaynaklı güçlü bir toplumcu gerçekçi anlayışa kaymıştır. İlhan Berk, bu döneminde halk edebiyatı motiflerinden şiirine bir hayli malzeme taşır. (...) İstanbul Şiiri, ekmeklerini alın terleriyle kazanan İstanbul'un küçük insanlarının macerasını anlatır." (Korkmaz, 2005, s. 272)

${ }^{18}$ Oval1, Arat, Türk Dili Dergisi, C. 22, S. 129, Kasım - Aralık 2008

19 "İlhan Berk, İstanbul'da yıkılmış, çirkin, içten içe kaynayan bir toplumun akislerini görüyor. Bu bakış tarzında, Marksist görüş kadar, şairin şahsi psikolojik durumunun da 
“İstanbul” şiirinde İstanbul'un bütün semtleriyle yeni bir güne uyanışını ressam titizliğiyle resmeden şair, o insanların umudunu, çalışkanlığını ve tevekkülünü dizelere taşımayı ihmal etmez:

"Istanbul açları tokları hastalarıla aynı kita üzerinde bulunuyor

Bu saatte dünyada sabahtır

Bu saatte yeryüzünün birçok limanlarına gemiler girip çıkar

Birçok insan balıktan döner

Istanbul bir göz bin dudak halinde ayakta

İște sirayla kalkan kepenklerin gürültülerini duyuyorum

Edirnekapı tramvaylarında iğne atsan yere düşmez

Sanki bir can pazarı kurulmuştur

Uyuyan şehirler evlerini Allah'ı sattyorlar" (Toplu Şiirler, s. 42 - 43)

İstanbul'un daha çok ekonomik koşullarıyla şiire girdiği bu dizelerde çalışkan, fakir halk sosyal bir sorun olarak şiire yansır. İlhan Berk'e göre İstanbul'daki yoksul ve açlığın temelinde bu şehre göç eden insanların sayıca fazla olmasının etkisi büyüktür. ${ }^{20} \mathrm{Bu}$ fotoğrafın yarattığı mutsuzluk şairi, şiirin kollarına iter:

"Bu saatte Istanbul insanı deli eder

Bu saatte yeryüzü çalışan insanların elindedir

Bu saatte düşman uykudadır

İstanbul'un çalışkan fakir halkını

İşleri başında görüyorum" (Toplu Şiirler, s. 12)

İlhan Berk, İstanbul'un yoksul işçilerinin trajedisinden bahsederken sosyal eleştiri yapmayı da ihmal etmez. Ona göre dünya adaletsizlik üzerine bina edilmiş ve böyle devam edecektir:

"Bu defa aç fakir İstanbul'u

Büyük surların dlşından seyredeceğiz

Bir anda fakirler işsizler sökün edecek

Önünden yorgun düşünceli yüzleriyle geçecekler

tesiri vardır. Berk, tedirgin, huzursuz, anarşik bir mizaca sahiptir.(...) " (Kaplan, 1996, s. 211)

20 "Şairin deyişiyle tok İstanbul'a akan 'aç İstanbul'dur. Sonra sokak sokak büyür kent; marangozlar, kitapçılar, manavlar, bakırcılar, berberler, terziler, eskiciler, kahveciler, mürettipler, tramvay işçileri, bekçiler, sokak kadınları, sarhoşlar yansır aynaya. Sürekli çalışır onlar" (Karaca, Alâattin; "Yahya Kemal'in İstanbul'undan İlhan Berk'in İstanbul'una", Hürriyet Gösteri, S. 296, Aralık, Ocak, Şubat 2008-2009) 
Ulutaş, N. / Sosyal Bilimler Araştırmaları Dergisi. 2, (2009): 129-149

\section{Yeniden açılacak köprü dükkânlar fabrikalar}

Yeniden katledilecek emeği fukara halkın" (Toplu Şiirler, s.54)

\section{Gündelik Hayat}

İlhan Berk'in şiirlerinde İstanbul'la ilgili göze çarpan diğer bir nokta da gündelik hayatı tasvirdir. ${ }^{21} \mathrm{Bu}$ tasvir II. Yeni Akımı'nın soyut ve kapalı anlatımı $^{22}$ yanında yer yer somut ve sosyal eleştiri yanıyla karşımıza çıkan bir tasvirdir:

"Durduğun yerden İstanbul köprüsü tramvayları mavnalarlyla sanki yürüyor

$\mathrm{Bu}$ sislerin ve bulutların arasından en son harekete geçen $\mathrm{Klz}$ Kulesi'dir

İste karnı karına vermiş motorlardaki balıkların üstüne yağmur yağıyor

Bir defa olsun akıllarına gelmemiştir

Gözleri pirll pirıl balıkların

Bir İstanbul göğ̈̈ altında ăglamak

Hepsi denizde geçen hayatlarını düşünüyorlar

Dokunsanız ağlayacaklardır." (Toplu Şiirler, s.42)

İstanbul'un gündelik hayatı içinde şairin gözüne en çok aç, yoksul insanlar ve balıkçılar takılır. Tramvaylarda iş dönüşü evine dönen kalabalık "Edirnekapı tramvaylarında iğne atsan yere düşmez" dizesiyle tasvir edilir:

"İstanbul açları tokları hastalarıyla aynı kıta üzerinde bulunuyorlar

Bu saatte dünyada sabahtır

Bu saatte yeryüzünün birçok limanlarına gemiler girip çıkar

Birçok insan balıktan döner

İstanbul bin göz bin dudak halinde ayakta

\footnotetext{
21 "Gündelik yaşayış sahnelerini tasvirden, zamanla nesre yaklaşan bir anlatıma yönelir. Zengin çağrışımlar, anlamsız, yı ğın tesiri uyandıran ifadeler, İstanbul yorumları, tarihe olumsuz bakış, cinsiyetle ilgili yer yer pornografiye ulaşan yoğun telmihler İlhan Berk'in şiirinden alınan ilk izlenimlerdir." (Enginün, 2002, s.115)

22 “İkinci Yeniciler, geleneği tümüyle dışlayarak içsel, bireyci bir şiir anlayışına yönelirler. 'Anlamsızlığın anlamı' ve 'anlamsızlı̆ga kadar özgür olmak' şiir anlayışlarının ana izleğidir. Hareketin öncülerinden İlhan Berk'in anlatımıyla; 'Sözün üstünü çize çize yürüyen' bir şiir dili vardır. Mitin sisli dünyasından kopardıkları nesneleri şiir dilinin buğusuyla kararak somut unsurlarından arındırılmış soyut ve belirsiz estetik bir dünya kurarlar." (Korkmaz, 2005, s. 269-270)
} 
Ulutaş, N. / Sosyal Bilimler Araştırmaları Dergisi. 2, (2009): 129-149

İste sırayla kalkan kepenklerin gürültülerini duyuyorum

Camlar siliniyor

Tramvayların havayl yarıp geçtiklerini görüyorum

Tünel'de vagonların ışıklarl yandı

Gülhane Parkl'na güneş vurdu

Fatih'teki "Garipler mahallesi" nde şimdi sade çocuklar kalmıştır

Edirnekap tramvaylarında iğne atsan yere düşmez"

(Toplu Şiirler, s. 42)

İlhan Berk'in şiirlerinde yer yer imgesel bir dil kullanması hem bağlı olduğu akımın hem de özgün karakterinin etkisiyledir. II. Yeni akımının en zayıf noktalarından biri aşırı imgeci anlayışa sahip olmasıdır. Bu anlayış, İlhan Berk de dahil olmak üzere bu akım sanatçılarına halktan uzak yaşayan aydın görünümü kazandırır. ${ }^{23}$ Gerek imgesel dili gerekse sanatkârane kişiliği onu yaşamdan koparmaz. Zaten o, şiiri yaşamın bir ürünü olarak algılar. ${ }^{24}$ "Vatandaş" şiirinde umut ve sevgiyle bağlandığı İstanbul'un gündelik yaşamını şiire yansıtan şair, bu şehirde yaşayan her insanın ayrı bir hikâyesi olduğuna değinir:

“Bir gökyüzü gördüm ki Ístanbul’da

Daha hiç biri görmemiştir insanların

Bulutlara baktım boyuna yer değiştiriyorlardı

Insanlara baktım hepsinin bir hikâyesi vardl

Bir çocuk durmuş denize işiyordu

Vapurları biri gelip biri gidiyordu

Ölüm çıkar buradan

Ama ben çıkmam dedim." (Toplu Şiirler, s.110)

\footnotetext{
${ }^{23}$ Korkmaz, 2005, s. 270

24 "Şiir yaşamdan çıkar. Bu söz çok su götürür, düşünüyorum birden. Böyle söz etmişim bir yerde. Şiir, şiirin tarihine eğilerek, onu örnekleyerek, ona bata çıka yazılır. Yoksa yaşamak sözü şiirin tarihinde çok gerilerde kalır. Bir şiiri bize büyük, iyi dedirten, onun bir başka büyük, iyi bir şiirden çıkması, onu anımsatması, onunla doğrulanması; dahası onunla yorumlanmasıdır. Bir şiirde yaşam böyle perçinlenmezse, şiir böyle vurmazsa (kendi tarihi içinde doğrulanmazsa), yaşam (bu ne denli boyutlu olursa olsun) sözde kalır. Yaşam·kadar eski bir şey yoktur çünkü.” (Berk, İlhan, Türk Dili, Eylül 1982 (Defterler I, 24 Mayıs 1982)
} 
Şiirde gündelik bir hayatı yansıtan şairin çizdiği tabloda, gökyüzü umudu ve yaşama sevincini simgelerken ${ }^{25}$ çocuğun denize işemesi, aslında yukarıda da belirttiğimiz gibi şairin bir çocuk vasıtasıyla İstanbul'a olan nefretini kusmasına karşılık gelir. İstanbul'daki olumsuzluklara rağmen şair, bu şehirden ayrılmamaya kararlıdır. Şiirde anne, umut, aşk, kadın, cinsellik, sonsuzluk gibi olumlu anlamlarla yüklü bir imge olan deniz ${ }^{26}$ İlhan Berk'in şiirinde sosyal ve ideolojik bir anlama bürünerek, şairi yalnızlığa sürükleyen bir gösterge olarak karşımıza çıkar. ${ }^{27}$

\section{E. İstanbul ve Yalnızlık}

Yalnızlık, şairin kaderidir. Şiirin ve şairin kaderi yalnızlık temi etrafında örülür. Divan şiirinden modern şiirimize kadar birçok şair, yalnızlık temini şiirine eksen kılmıştır. Özellikle 20. yy insanı büyük kırılmaların pençesinde, vefasızlık ve yalnızlık buhranlarıyla kıvranmaya devam etmektedir. İlhan Berk'in yalnızlığ 1 , çocukluğuna dayanır. ${ }^{28}$ Şair, özgeçmişini anlattığ1 "Otobiyografi”" şiirinde yaşadıklarını, kişilik yapısını, ürkek ve utangaç tavırlarını okuyucuyla paylaşır. ${ }^{29}$

\footnotetext{
25،i̇lhan Berk'in şiirlerinde de gökyüzü hürriyet ve kurtuluşun sembolü olarak sık sık tekrarlanıyordu.” (Kaplan, 1996, s. 311)

${ }^{26}$ Akgün, 2002

27 "Burada şairin "su" unsuruna çok belirli olmamakla beraber, sosyal veya ideolojik bir mana yüklediği hissolunuyor. Fakat yukarda zikretmiş olduğumuz örnekler, bu mananın altında cinsi bir mananın bulunduğunu açıkça gösteriyor. Freud, Jung ve daha başka psikologlar insanların, dış alem karşısında almış oldukları tavırlar üzerinde sosyal çevrenin tesirini kabul etmekle beraber, gayrişuuri amillerin, bilhassa cinsi temayüllerin büyük rol oynadığını ileri sürerler. Bu görüşe dayanarak biz öyle sanıyoruz ki, İlhan Berk'in asli temayülünü tayin eden başlıca amil, "su" unsurunu, yahut onun tekabül ettiği anne imagosu veya "anima archetpe"dir." (Kaplan, 1996, s. 204 - 205)

28 "Manisa'da esnaf olan babasının başka bir kadınla evlenmesi nedeniyle İlhan Berk'i annesi büyütür. Demek İlhan Berk, birden bire kendi seçtiği bir yaşta doğuvermiş. Geçmişini istediği yerden başlatmış, bütün ön hazırlıklarını kendi başına ve kendi içinden halletmiş. Eskiye ödün vermeden, bir gün, hazırlıklı çıkmış ortaya. Acemilik çekmeden." (Ünlü ve Özcan, 1990, s. 325)

29 “ïlhan Berk,1918,Manisa, Boy: 1.70, göz: kara,renk: buğday. Bir insan herkes gibi.

Bir fotoğrafta uzun pantolonlar, uzun saçlar,uzun kollar. Bilinmez niçin?

Bir açık hava fotoğrafi, güneşli, duru Ayaklarına düşüyor gölgesi bir ağacın

Uzun saçları uzun yüzüne vurmuş

Ve yanında duruyor deli ablası

(Hep soyunuk dolaşan ve topuklarına çıkan saçları)

Gök boş

Önüne bakıyor, ürkek, utangaç ve ayakta
} 
"22 Temmuz 1950" başlıklı şiirinde, yaşadıklarından efkarlanan ve İstanbul'da yalnızlığına ağlayan bir İlhan Berk'le karşılaşırız:

"Hava ballk ve rak kokuyordu Istanbul'da

Bir kış günüydü kendimde değildim

Uzakta bir pencere duruyordu

Ben pencereye bakıp ağlamıştım." (Toplu Şiirler, s. 105)

Şiir; şairin yalnızlığına kadının, kadının hatıralarına şairin ortak olmasıyla sürer. Şair ve kadın yalnızlığın pençesinde hatıralarına ağlarken İstanbul hayata kaldığ 1 yerden devam eder:

"Dünyada kadınlar erkekler çocuklar vardı

Dünyada ağlayan gülen insanlar vardl

Dünyada bir Istanbul vard $k i$

Safi rakı kokardl" (Toplu Şiirler, s. 105, 107)

"Beş Atlı Erzurum'a Geceyle Beraber İndik" şiirinde şairin yalnızlığı ve umutsuzluğu hangi şehirde olursa olsun onu bulur. Bu yalnızlık ve umutsuzluk aslında tüm insanların yüreklerini kavuran bir yaradır:

"Sivas'ta Konya'da Bursa'da İstanbul'da

Yalnızız.

Sivas 'ta Konya'da Bursa'da Ístanbul'da

Umutsuzuz." (Toplu Şiirler, 186)

İlhan Berk, Galile Denizi kitabında yer alan, "Balad" şiirinde İstanbul'u kirli ve yalnızlığını örtemeyen bir şehir olarak tasvir eder. İstanbul'un sahip olduğu kirlilik Fikret'in Sis şiirinde de görülen şairin psikolojisinden kaynaklanan olumsuz bir bakıştan kaynaklanan kirliliktir. Şairin bu kitabında çizdiği manzara, toplumsal gerçekçi şiir anlayışına bağlı olarak sefalet sahnelerinin çizildiği, halkın sıkıntılarla yaşadığ 1 bir manzaradır. İlhan Berk'in diğer şairlerden farkı sıkıntılar içinde umutlu günleri müjdeleyen bir karaktere sahip olmasıdır. Ona göre sıkıntıları aşmanın yolu aşkı yaşamaktan geçer:

"Böyle güneşlere baylliyorum çok güneşlere

Hafif otlar yürüyor evlere pis İstanbullara

Şey ile şeysiz geçiyorum o kapanık güneşlerde

Böyle koşmaya başlar yeryüzünü

Önüne bakan gözleri solgun (Biliyoruz solgun okullarda) yetişmiştir ve ancak bayramları tutmuştur babasının elinden)

Bodur, kara, kunt babasının (bir yığın elli bir yığın kadınla yattığından) (T. Ş, s.697) 
Ulutaş, N. / Sosyal Bilimler Araştırmaları Dergisi. 2, (2009): 129-149

Siz bir durma benim karanlığımı yadsıyorsunuz

Sokağa çıkmayın diyorum çıkmayın duymuyorsunuz

Benimle gelen o büyük sikıntıdan gelenlerdi

Ta Galile içlerinden yürüyerek gelmişlerdi

Biriniz beni görmediniz ne kadar bağırdımsa

Denizler baktığım tüm o denizler gösterdi bana

Bir yalnızlık yeryüzündeki kapılar bir o gördüm

Bir deniz size de gelir vurur elbet anlarsiniz.’'(Toplu Şiirler, s.245)

\section{F. İstanbul'da Aşk ve Şehvet}

Aşk, şiirin vazgeçilmez temidir. Şairin gıdasıdır. İlhan Berk'in şiirlerinde de aşk vazgeçilmez bir temadır. O, şiirlerinde yaşadığı aşkı özlemle, tutkuyla bazen de şehvetle yaşar. Onun toplumsal temalı şiirlerden aşk temalı şiirlere geçişi kolayı seçmesi olarak yorumlansa $\mathrm{da}^{30} \mathrm{o}$, bu konuda aşk1 yalnızlıkla üleştirdiğini söylemekle yetinir: "Eskiden benim konularım özgürlük, aşk, mutluluk, baskıya karşı koyma ve Anadolu'ydu. Sonra bunların yerini salt aşk aldı. Çivi Yazısı, Otağ'da bunlara yalnızlık da karıştı." ${ }^{31}$ Onun toplumsal temalı şiirlerden aşk şiirlerine geçişi, sükûneti burada bulmasına, zirveye buradan erişmesine bağlanabilir.

20 Haziran 1949 tarihli, "Sabahları" adlı şiirde aşk, İstanbul'la birlikte, yüreğinin sesine şöyle karışır:

"Bir pazartesi sabahı seni düşündüm

A ̆gaçlara ve gökyüzüne bakarak

Istanbul gözlerin gibi pırll pırıld

Denizin dibinden geçen balıkları gördüm

Seni düşündüm de ağlamak geldi içimden

Sonra beni elimden ayă̆ımdan

Sonra beni bu kadar senden eden İstanbul'a

Dönüp merhaba dedim." (Toplu Şiirler, s. 102)

\footnotetext{
30 “İlhan Berk, 1940 kuşağı toplumcu șairleri arasında yer aldığında șiir anlayıșının II. dönemi egemendir. 1947- 1955 yılları arasında geçen 8 yıl, yayımladığı ürunlerle toplumcu Türk şiirine, sanatına, kültürüne katkıda bulunmuş, yararlı olmuş, zengin anlatımı, ince duyarlığı ve geniş imge gücüyle birçok toplumcu şairi de etkilemiştir. Ama 1958 sonrası işin kolayına kaçıp toplumcu olmanın karşılaştırdığı sorunları gögüsleyemeyerek bu yoldan dönmüştür." (Ünlü ve Özcan, 1990, s. 326)

${ }^{31}$ Ünlü ve Özcan, 1990, s. 326
} 
Bu şiirde şair, İstanbul'u sevgilisinin gözlerine eşdeğer bir şehir olarak düşler. Sevgilisini kendisinden ayıran bu şehre merhaba diyen şairin yalnızlığı yüreğine biriken gözyaşlarına siner. "Siz Ne Güzeldiniz Benimle Bilemezsiniz" adlı şiirde İstanbul, aşkın ve yalnızlığın şehri olarak şiire girer:

"Şimdi kim bilir İstanbul'sunuz değilsiniz

Birf'ydiniz Önasya'larda o şey evlerde

Şimdi nasıl bir yalnıllk eser yeryüzünde

Uzun sular olur duymak gibi bir şeydiniz." (Toplu Şiirler, s.254)

İlhan Berk'in harf simgesiyle oluşturduğu dize yapısına burada da rastliyoruz. O, harfler ve rakamlarla oynamayı seven bir şair olarak şiirde İstanbul'u yalnızlığın şehri olarak tanımlar. Kendisini toplumsal temalardan aşk ve yalnızlığa iten en önemli sebebin, bu tür temalar için düzyazının daha uygun olduğuna inanması ve yalnızlığına olan sevgisi olduğunu ilân eder. ${ }^{32}$

"Saint - Antoine'ın Güvercinleri” şiirinin "Eleni'nin Elleri” adlı bölümünde İstanbul, Eleni ile İlyadis adlı iki gencin aşklarını taşır içinde. Şair, çocukluğundan bir hatıra gibi taşıdığı bu aşk hikâyesini âdeta kendi aşkıyla özdeşleştirir:

"Bir evdeydi

Eleni on sekizinde, Illyadis yirmi üç

Eleni'nin şarkılarl vard

Insan akul erdiremezdi

Istanbul'un her tarafi kahve

Kapalı kahve açık kahve

Şarkllar ne kadar güzel olursa olsun

Eleni'yi anlamazdl" (Toplu Şiirler, s.202)

Eleni'nin Elleri, toplumsal temalı şiirlerden bireysel temalı aşk şiirlerine geçişin bileşkesi gibidir. $\mathrm{O}$, bu şiirde 23 yaşındaki bir delikanlı ile henüz 18'inde bir genç kızın zorluklara dayalı aşkını işler. Erkek, yıllar sonra bu

32 "Salt, o eski kitaplarımdaki toplum şiirlerini, bugün, düzyazının rahat rahat yapabileceğine inanmam bir neden olabilir. Kısaca onların şiir olmadığını söylemek istiyorum, yoksa bir şiirin toplumsal olması, onun şiir olmamasını gerektirmez. Şunu demek istiyorum ben, bugün o tarzda anlamıyorum toplumsal şiiri, yoksa asıl bugün toplumsal şiir yazdığımı sanıyorum. Şiiri anlamam değişti, diye özetleyebilirim bunu. Bugün aşkları, yalnızlıkları, bunaltıyı yazıyorum. (...) Aşklar, yalnızlıklar daha bir ağır basıyor. Ben yalnız bir adamım, yalnızlığımı da korkunç seviyorum.” (Menemencioğlu, Muazzez, “İlhan Berk’le Söyleşi”, Varlık Dergisi, 1 Nisan 1962) 
aşkını hatırlayıp efkârlanmıştır. İstanbul, bu aşkın belki de tek şâhididir. Şâir, âşığın gözlerinden bakar Eleni’ye. Kendini âşığın yerine koyar. Hayatını Eleni'den önce ve sonra olmak üzere iki evreye ayırır. Eleni, gelince her şey değişir. İlk önce İstanbul, şiirden çıkıp yerini alır, bir çocuk güler ve ağaçlar çiçek açar. Şair, hayatını Eleni'den sonra başlatır. Eleni, şairin hayatını anlamlandıran ve ona hayatı fark ettiren kişidir.

Eleni gelince, sokaktan bir deniz görünüyor. Deniz, burada "umut" ve "aşk"1 simgeleyen bir imge olarak kullanılır. Şiirin genelinde aslında şairin iç konuşmayla ruhuna seslendiğine şahit oluruz. "Bak Ilhan Berk köprüden geçiyor ruhum, duyuyor musun?" dizeleri bu yaklaşımı imliyor. Şiirde, zaman zaman geriye dönüşlerle geçmişine giden şair, eski aşkları ve yaşantıları anıyor. Gerçek hayatın çelişkileri ve mutsuzluklar da bu iç konuşmalardan payını alır.

"Aldı Çiçekçi Çingene Kadın" adlı şiirde İstanbul'a renk veren Rum çiçekçilerden yola çıkan şair, şehrin değişimini ironik bir dille ele alır:

“ $N$ ' oldu bu İstanbul'a

Ne Sevim ne Yanula biri yok

Anlamıyorum doğrusu

Karidesçi bu dünyayı koyup gitsin. " (Toplu Şiirler, s.224)

İlhan Berk, şiirini kurarken sürekli bir değişimi ön görür. ${ }^{33} \mathrm{O}$, bu şiirde İstanbul'un kendine has dokusunun çeşitli şekillerde yok olduğunu çiçekçilerden yola çıkarak anlatır. Sevim ve Yanula muhtemelen şairin gönlünde yer etmiş Rum güzellerdir. İstanbul, onlarla birlikte kendini de kaybetmiştir.

Çivi Yazısı kitabında yer alan "Ben Senin Krallığın Ülkene Yetiştim" başlıklı şiir, İlhan Berk'in imgesel bir dille, aşk1 yoğun olarak işleyen şiirlerinden biridir:

"Sen o çıktığım sularsın, zencim benim

Denize bakan evler gibiydim seninle

Sen gittiğim o ülkesin varılmıyorsun

Vurmuş sonrasız nasıl en güzel sulara

Güzelliğin balıkları gibi İstanbul'un

\footnotetext{
33 'İlhan Berk, bir dil trapezcisidir ve sürekli olarak değişimi şiiri için bir çıkış yolu olarak seçmiştir. Devamlı yeni kalmak uğruna bir önceki dönemini yadsıyarak kendisine ters düşer. Aykırılık, onun şiirinin doğasını oluşturur. Sürekli değiş̧imi şiirini ayakta tutabilmenin tek yolu olarak görür. Bunun için dur durak bilmeksizin şiir dilinin sınırlarını zorlar." (Korkmaz, 2005, s. 272)
} 


\section{Şimdi her yerde ne güzeldiniz o kalmış}

Yankımış denizlere öbür kadınlara

Dünyada sizinle İstanbul olmak varmış.” (Toplu Şiirler, s.255)

Jose Oltegay Gasset, "Aşk Üzerine” denemesinde şöyle der: "Aşk, kişiliğimizin derinliklerinden çıkan bir soluktur. Aşk, statik bir şey değildir. Sevilen kimse için yapılan bir hamledir. Heyecansal bir eylemdir. Kendisi için sevilen bir başkasının varlığına isteyerek katılmak tarzıdır. Seven kimse, varlığının derinliklerinde aşkının konusu ile tam olarak birleştiğini sezer. Onlar "ontolojik ve hayatî bir bütünlük" meydana getirirler. Aşk, bir tamlık özlemidir. Aşkı çekici yapan şey, seven varlığın kendi varlığ karşısında metafizik anlamda saydamlaşmasıdır. Seven kimse en büyük tatmini sevdiği varlıkla tam bir kaynaşmada bulur." "34 "Deniz"i sevgili veya mutluluk olarak ele aldığımızda, şair onu seyreden âşıktır. Sevgili, ona saadet bağışlayan suya benzer. Ona huzur verir. Şairin tek isteği kalır, bu aşktan geriye; o da sevgiliyle birlikte İstanbul olmak.

"Siz Dedim De F, O Denizler Aldı Beni" adlı şiirde gizemli "F" bir kez daha karşımıza çıkar ve Truva dönemi sembolleriyle İstanbul'la bütünleşen bir aşkın adı olur:

"Siz dedim de f, o denizler aldı beni

Sabah haliniz o eski sularl geçtim

Helene'nin baktığ denizlerde Paris'tim

Yeni sesler buldum, renkler, diller yeni

Kral yalnızlıklarımda düşündüm sizi

$O$ çok günler Çin denizlerinde gittim

Sular, güneşler onlardı karşılaşıtırdım

İstanbul gibiydiniz belki daha da yeni. "(Toplu Şiirler, s.256)

$\mathrm{Bu}$ şiir de Antik Yunan kahramanlarından yola çıkarak aşkı işleyen bir şiirdir. Bu şiirde de içerikle teknik sağlamlığın iç içe kullanıldığına ve telmih sanatıyla, okuyucuyu geçmişle yüzleştirdiğine şahit oluruz.

"Kıyı" adlı şiirinde, sevgilinin güzelliği ve sevgiliye duyduğu aşk, İstanbul olarak yansır şiire:

"Ey dirliğim eskim tükenmezim sen

Gögüm İstanbul'um değişmezim sen

(...)

${ }^{34}$ Schwarz, 1971, s. 160 


\section{Yapră̆ım sı̆̆lı̆̆ım beyaz som gülüm}

Aşkım kıyım yenim İlhan Berk'im sen”" (Toplu Şiirler, s.332)

Klasik şiirde de rastladığımız sevgilide / aşkta fenâ (yok olma)'ya bu şiirde de rastlarız. Şair, aşkını yaşarken sevgilide sonsuzluğa ulaşır. Ona, olan aşkını "İstanbul'um" diyerek gösterir. Sevgili, en az İstanbul kadar çekici ve etkileyicidir. Şair, hayatın kalabalığından sevgilinin kıyısına sığınır.

İstanbul, "İstanbul” adlı şiirde, yalnızca aşkın değil; şehvetin de şehri olarak şiire girer:

"Ístanbul'u ilk aydınlıkta görüyorsun

Bu şehir aşktan değil şehvetten düşüp gebermeye hazır

(...)

Seni düşünüyorum

Sen genç orospular ölü padişahlar frengililer şehri

Seni demir parmaklıkların arkasından seyrettim” (Toplu Şiirler, s. 56)

İlhan Berk'in bu şiirinde İstanbul, aşktan değil, şehvetten ölmeye hazır bir şehirdir. O, kutsal aşkların olduğu gibi, aynı zamanda; "genç orospular, ölü padişahlar, frengililer şehri" dir. Şair, bu şiirinde okuyucuyu daha çok Beyoğlu, Galata gibi semtlerle öne çıkan, İstanbul'un öteki yüzüyle karşılaştırır. Şehvet ve erotizm aslında İlhan Berk'in hayatında ve şiirinde zaten vardır. ${ }^{35} \mathrm{O}$, özellikle resimlerinde kadını çıplak ve erotik çizgilerle yansıtmaktan hoşlanan bir şairdir. ${ }^{36}$

\footnotetext{
35 "Doğrusu erotizm, benim büyük konularımdan biridir. Erotizm, benim kendi insan boyutum içinde, bana en yakın yermiş gibi geliyor. Çocukluğuma indiğim zaman büyük aşklar göremiyorum. Yani ben, aslında çocukluğumu yaşamadım. Bir kızın, bir kadının eline dokunmak: bir kızı, bir kadını sevme olayı, bende sanıyorum ki, çok geç yaşlarda başladı. Sanırım, beni erotik temalara iten de bu oldu. Şiirlerimde bu konuya yönelmem de bu yüzden.” ( Berk, 2005, s. 32)

36 "Bir de ressam İlhan Berk vardır. Nü’ler çizer kâğıtlara, kitap sayfalarına, her yere. Nü'ler; deforme olmuş kadınlar; var olan kadınlar değil, çizgiden ibaret kadınlar; ama mutlu çizgilerdir bunlar. Çünkü İlhan Berk için resim yapmak mutluluk, yazmaksa cehennemdir. Resim aracılığıla dünyayı olduğu gibi görmez ve en önemlisi kendisine yeryüzünü cehenneme çeviren yazmak eyleminden kurtulur. Kadınlar bu nedenle kalın birer çizgidirler şiirinde. "Mutlu insan yazmaz, yazmak mutsuzluktur' diyen İlhan Berk'in şiirinde kadının ayrıcalıklı bir yeri yoktur; "Her nesne nasılsa kadın da öyledir" hatta. Ama resminde kadın mütemadiyen Nü'dür. Kadın demek resim demektir neredeyse, yani mutluluk..." Özdemirciler, Faize, "Kadın Bir Nü, Aşk Bir Resim, Şiir Büyük Eziyet...” " http//www.afrikapazarı.net. (28 Eylül 2008/Pazar)
} 
Sonuç olarak İstanbul, İlhan Berk'in şiirlerine hemen bütün çehreleriyle yansır. Şair, bazı şiirlerinde bu şehri bir medeniyet merkezi, bir kültür dokusu olarak ele alırken; bazı şiirlerinde yalnızlığının, aşklarının ve çelişkilerinin kesiştiği ayna olarak algılar. İstanbul; onun şiirlerinde sadece coğrafî güzelliklerin buluştuğu mekân değil aynı zamanda toplumsal olumsuzlukların yaşandığı işçilerin, balıkçıların, aç insanların trajedilerinin tercümanı olan yerdir. Şair, İstanbul'dan yola çıkarak çıkmazlarını, çelişkilerini ve hayal kırıklıklarını da şiire yansıtır.

\section{Kaynakça}

Akgün, Ali, İlhan Berk Şiirinde Nesne Sorunu, (Yayınlanmamış Yüksek Lisans Tezi, Bilkent Üniversitesi, Türk Edebiyatı Bölümü, Ankara, Haziran 2002

Akkanat, Cevat, Gelenek ve İkinci Yeni Şiiri, Kültür Bakanlığı Yayınları, Ankara, 2002

Berk, İlhan, Kanatı At, Yapı Kredi Yayınları, İstanbul, 2005

Berk, İlhan, Toplu Şiirler, Yapı Kredi Yayınları, İstanbul, Mart 1993

Berk, İlhan, Türk Dili, Eylül 1982 (Defterler I, 24 Mayıs 1982

Enginün, İnci, Cumhuriyet Dönemi Türk Edebiyatı, Dergah Yayınları, İstanbul, 2002

Kaplan, Mehmet, "Türk Edebiyatında İstanbul”, Türk Edebiyatı Üzerine Araştırmalar, Dergâh Yayınları, İstanbul, 1999

Kaplan, Mehmet, Şiir Tahlilleri - II (Cumhuriyet Devri Türk Şiiri), Dergâh Yayınları, İstanbul, 1996, s. 209

Karaca, Alaattin, "İlhan Berk'in Şiir - Resim Etkileşimi”, Türk Edebiyatı, S. 423, Ocak 2009

(http://www.yeniturkedebiyati.com/makale/cumhuriyet_devri_turk_edebiyati/530-ilhanberkte-siir-resim-etkilesimi-doc.-dr..html)

Karaca, Alâattin; "Yahya Kemal'in İstanbul'undan İlhan Berk'in İstanbul'una", Hürriyet Gösteri, S. 296, Aralık, Ocak, Şubat 2008-2009

Korkmaz, Ramazan, Yeni Türk Edebiyatı (1839-2000), Grafiker Yayınları, Ankara, 2005

Menemencioğlu, Muazzez, “ilhan Berk'le Söyleşi”, Varlık Dergisi, 1 Nisan 1962

Nesin Vakfı Yıllı̆ğ - 1976, Tekin Yayınları, İstanbul, 1976

Ovalı, Arat, Türk Dili Dergisi, C. 22, S. 129, Kasım - Aralık 2008

Özdemirciler, Faize, "Kadın Bir Nü, Aşk Bir Resim, Şiir Büyük Eziyet..." http://www.afrikapazar.net"

Schwarz, Oswald, Cinsiyet Psikolojisi, (Çev.Halis Özgü), Özgü Yayınevi, İstanbul, 1971

Ulutaş, Nurullah, "Ziya Paşa ve Tevfik Fikret'in İstanbul'a Bakışı”, Seyir, S. 4, Bahar 1998, s. 31-32

Ünlü, Mahir; Özcan, Ömer, 20. Yüzyıl Türk Edebiyat,, İnkılâp Kitabevi, İstanbul, 1990 